\title{
Mood, Modality and Polarity Analysis of Winston S. Churchill's Speech on Hitler's Invasion of the U.S.S.R
}

\author{
Chen Liping \\ 1School of Foreign Languages, Guangdong University of Petrochemical Technology, \\ Guangdong, China
}

\begin{abstract}
This paper analyzes a famous speech by Winston $S$. Churchill from the perspective of mood, modality and polarity with the aim to find out how interpersonal function is realized in the speech. It is found that the use of more declarative sentences, modal auxiliaries with high value and the negative polarity helps enforce the persuasive power of the political speech.
\end{abstract}

Keywords: mood, modality, polarity, political speech.

\section{INTRODUCTION}

In Halliday's Systemic Functional Grammar (SFG), language is used "to organize, understand and express our perceptions of the world and of our own consciousness"; "to enable us to participate in communicative acts with other people, to take on roles and to express and understand feelings, attitude and judgments"; "to relate what is said (or written) to the real world and to other linguistic events". These are the ideational, interpersonal and textual metafunctions of language. Halliday studies the three metafunctional meanings in terms of transitivity, voice, polarity; mood, modality and key; and theme, information and cohesion respectively. The theories of the three metafunctions by M.A.K. Halliday will be taken as the theoretical framework of this paper. It is hoped that the study may serve to show how interpersonal function is realized in Churchill's Speech on Hitler's Invasion of the U.S.S.R in terms of mood, modality and polarity.

\section{MOOD ANALYSIS}

According to Halliday (1994/2000:68-69), the most fundamental types of speech roles, which lie behind all the more specific types that we may eventually be able to recognize, are just two i) giving, and (ii) demanding. Cutting across this basic distinction between them is another distinction, equally fundamental, that relates to the nature of the commodity being exchanged. This may be either (a) goods-\&-services or (b) information. These two variables, when taken together, define the primary speech function of OFFER, COMMAND, STATEMENT, and QUESTION. It is mood that expresses the speech function (ibid: 363). Fig. 1 shows the examples of giving or demanding, goods-\&-services or information. 
Fig. 1 Giving or demanding, goods-\&-services or information

\begin{tabular}{|l|l|l|}
\hline \multicolumn{1}{|c|}{$\begin{array}{l}\text { Commodity } \\
\text { Role exchange }\end{array}$} & (a) goods \& services & \\
\hline (6) giving & $\begin{array}{l}\text { "offer" } \\
\text { Can I help you? }\end{array}$ & $\begin{array}{l}\text { "statement" } \\
\text { He's helping an old lady. }\end{array}$ \\
\hline (ii) demanding & "command" & $\begin{array}{l}\text { "question" } \\
\text { Help the old lady! }\end{array}$ \\
\hline
\end{tabular}

Mood in SFG puts emphasis on the way in which the information is given, either in spoken or written form. There are four kinds of mood structures: declarative, imperative, interrogative and exclamative. With declarative sentence, the subject position of the speaker or writer is that of a giver (of information), and the addressee's position is that of a receiver; with the imperative, the speaker/writer is in the position of asking something of the addressee, or requesting them to do something, while the addressee is supposed to comply. With the interrogative, the speaker or writer is asking information of the addressee, while the addressee is to provide the information. With the exclamative, the speaker/writer expresses feelings to influence the addressee. The choice of mood reveals the relations between the addresser and the addressee. The distribution of mood structures in Speech is shown below.

Table 1 The distribution of mood structures in Speech

\begin{tabular}{|l|l|l|l|l|l|}
\hline \multicolumn{1}{|c|}{$\begin{array}{l}\text { Mood } \\
\text { Structures }\end{array}$} & $\begin{array}{l}\text { Declarative } \\
\text { clause }\end{array}$ & $\begin{array}{l}\text { Imperative } \\
\text { clause }\end{array}$ & $\begin{array}{l}\text { Interrogative } \\
\text { clause }\end{array}$ & $\begin{array}{l}\text { Exclamative } \\
\text { clause }\end{array}$ & $\begin{array}{l}\text { Total } \\
\text { Number }\end{array}$ \\
\hline $\begin{array}{l}\text { Clause } \\
\text { Number }\end{array}$ & 70 & 2 & 1 & 0 & 73 \\
\hline Percentage & $95.9 \%$ & $2.7 \%$ & $1.4 \%$ & $0 \%$ & $100 \%$ \\
\hline
\end{tabular}

From Table 1, it is easy to find that declarative clauses make up a great majority (95.9\%) of all clauses, with imperative only $2.7 \%$, interrogative $1.4 \%$ and no exclamative clause. Since it is a televised political speech, the speaker is in a position very similar to that of a writer for there is no possibility of feedback from the listeners. In that case, declarative clauses, imperative clauses and some self-questioning interrogative clauses are best choices for the speakers. The high dominance of declarative clauses is the demand of political speeches because declarative clauses sound more objective than other kinds of clauses. In this speech, Churchill assumes that he is the information giver. His major task is to provide the public with facts, views objectively so that the audience will understand the situation and accept his viewpoints easily. 
Ideology is another important feature of political speeches. It is often realized by imperative sentences, especially "Let" imperative sentences. In a good public speech, especially when its speaker enjoys a high reputation in the audience, "Let" imperative sentences can be of great help in girding up people for action (Wang \& Ding, 1987:235, cited from Nong, 2006). At the end of this speech, after stating "reality" objectively and making people fully understand the necessity and urgency of taking military action against Hitler, Churchill uses two imperative sentences "Let us learn the lessons already taught by such cruel experience. Let us redouble our exertions and strike with united strength while life and power remain" to urge his people into action. So the use of imperative sentences is an effective method for the politician to achieve his political goals.

It is worth mentioning that there is only one interrogative clause in the speech "...but can you doubt what our policy will be?". It is a question in form, but it is in fact a self-questioning clause requiring no answer. It is used here to assure the British people that their policy is absolutely right. The interrogative clause clearly shows that Churchill is confident of his decision and what he says is unassailable.

\section{MODALITY AND POLARITY ANALYSIS}

Halliday (ibid: 88) points out that polarity is the choice between positive and negative, as in is/isn't, do/don't. Typically, in English, polarity is expressed in the Finite element; each Finite operator has two forms, one positive, is, was, has, can, etc., the other negative, isn't, wasn't, hasn't can't (or is not, can not...). However, the possibilities are not limited to a choice between yes and no. There are intermediate degrees: various kinds of indeterminacy that fall in between, like "sometimes" or "maybe". These intermediate degrees, between the positive and negative poles, are known collectively as modality.

Halliday (ibid: 356) defines modality as the area of meaning that lies between yes and no- the intermediate ground between positive and negative polarity. It can be divided into two types: Modalization and Modulation.

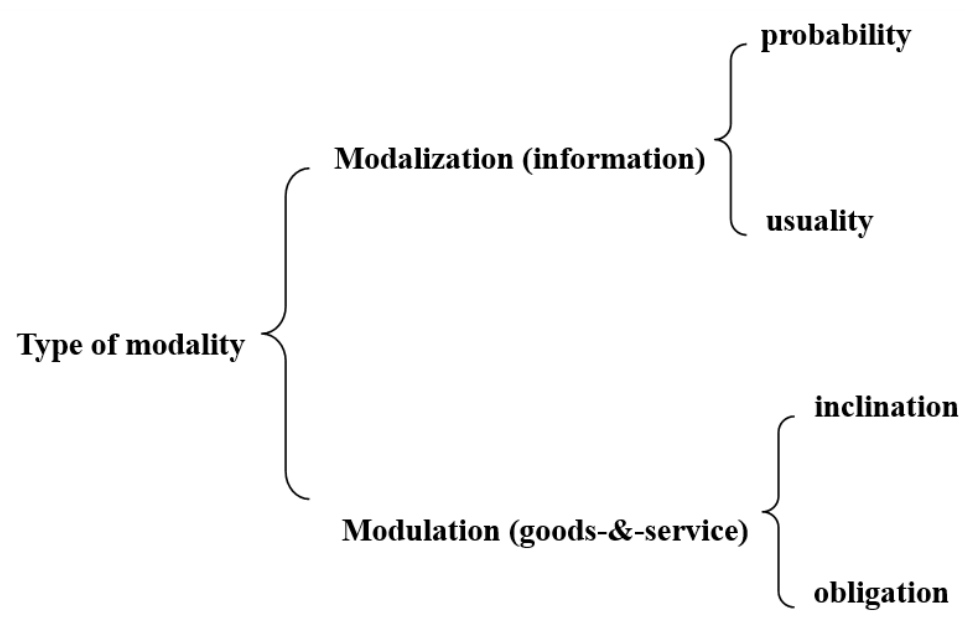

Fig. 2 Types of modality (Thompson, 1996/2000: 58)

From the figure above, we learn that the function of language determines the different types and sub-categories of modality. When language functions as a proposition to exchange information, which means "maybe" or "sometimes", there are two possibilities co-existing in modalization: Probability and Usuality. When language functions as a proposal to exchange goods-\&-service, there are also two kinds of possibilities in modulation: Obligation and 
Inclination, which distinguish command from offer. In a command, the intermediate points represent degrees of obligation, while in an offer, they represent degrees of inclination. The four types of modality are all varying degrees of polarity, different ways of construing the semantic space between the positive and negative poles (Halliday, 1994/2000:357). Thus we can see that the skillful application of modulation will help the speaker impose his idea upon others. A more detailed program set out by Halliday shows us the relation of modality to polarity and mood.

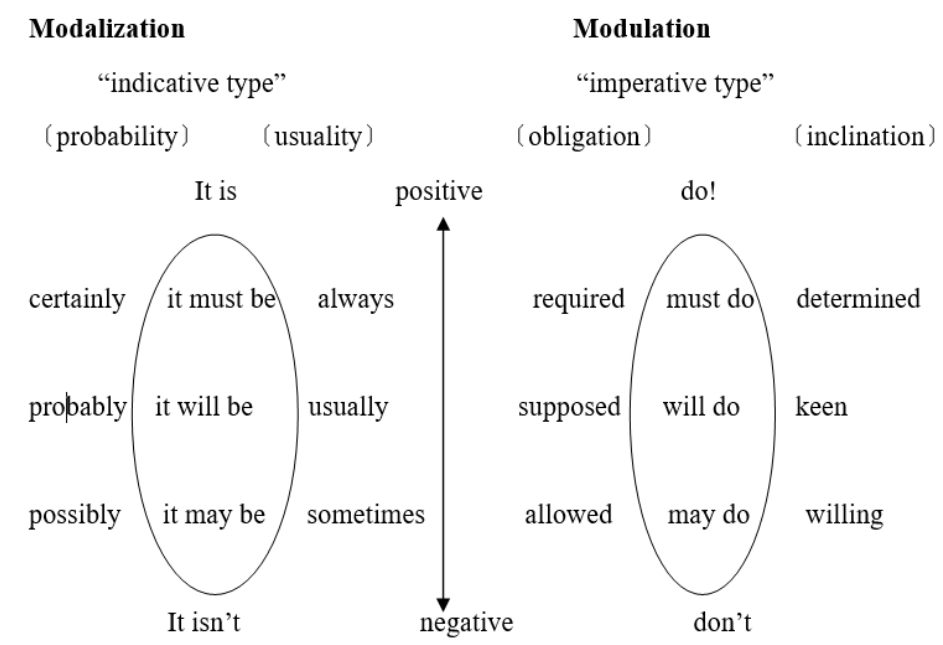

Fig. 3 Relation of modality to polarity and mood (ibid)

From this figure, we find that modal operators decide whether a clause is a proposition or a proposal. Since Halliday (ibid: 358,362) points out that modality has three values: high, median or low, the modal operators have, too.

Table 2 Three "values" of modality (ibid: 358 )

\begin{tabular}{|l|l|l|l|l|}
\hline & Probability & Usuality & Obligation & Inclination \\
\hline High & Certain & always & required & determined \\
Median & probable & usually & supposed & keen \\
Low & possible & sometimes & allowed & willing \\
\hline
\end{tabular}

Table 3 Three "values" of modal operators (ibid: 362)

\begin{tabular}{|l|l|}
\hline High & must, ought to, has to, is to \\
\hline Median & will, would, shall, should \\
\hline Low & may, might, can, could \\
\hline
\end{tabular}

\section{Modality Analysis}

Generally speaking, modality refers to a speaker's attitude towards, or opinion about, the truth or event described by a sentence (Simpson, 1993, cited from He, 2006). It relates to modalization on one hand: how likely it is to be true or how frequently it is true, and modulation on the other: to what degree the command or the compliance is affected. Modality is a major component to present interpersonal function of language and has been extensively studied in political speeches. 
Modality is expressed by three categories of modal operators: modal auxiliaries, modal adverbs, and modal adjuncts. Since modal adverbs and modal adjuncts are less used in Speech, the present author will study modality with the focus on modal auxiliaries. The following is a calculation of the occurrence of modal auxiliaries in Speech.

Table 4 Occurrence of modal auxiliaries in Speech

\begin{tabular}{|l|l|l|l|l|l|l|l|l|}
\hline $\begin{array}{l}\text { Modal } \\
\text { auxiliaries }\end{array}$ & will & shall & $\begin{array}{l}\text { must } \\
\text { (have } \\
\text { to) }\end{array}$ & would & should & can & may & could \\
\hline Occurrence & 15 & 8 & 4 & 4 & 3 & 3 & 2 & 1 \\
\hline
\end{tabular}

In Speech, Churchill uses 40 modal auxiliaries, in which the modal will, shall, must and would appear most frequently. In the following part, we will have a detailed discussion about the uses of them with the purpose to discover how Churchill conveys his ideas and persuades the audience.

\section{Will/Shall \& would}

The modal will/shall and would are used to express intension and futurity. It is known that politician's speeches tend to be future-oriented. In our case, Churchill broadcasts to the public, demanding people's support of the decision against Hitler. It is expected that he will focus on what he/they will do and what life will be like after they do so.

When will/would is used to provide information about what will happen in the future, it functions as modalization of possibility. The statement made about future occurrences are necessarily based upon the speaker's beliefs, predictions and intentions, rather than upon his knowledge of "fact". For example,

1. We will never parley, we will never negotiate with Hitler or any of his gang.

2. Any man or State who fights against Nazism will have our aid.

3. I have to declare the decision of His Majesty's Government,--and I feel sure it is a decision in which the great Dominions will in due course concur--for we must speak of now at once, without a day's delay.

4. He hopes, no doubt, that all this may be accomplished before the Winter comes and that he can overwhelm Great Britain before the fleets and air power of the United States will intervene.

5. He hopes that he may once again repeat, upon a greater scale than ever before that process of destroying his enemies one by one by which he has so long thrived and prospered, and that then the scene will be clear for the final act, without which all his conquests would be in vain--namely, the subjugation of the Western Hemisphere to his will and to his system.

6. He hopes that he may once again repeat, upon a greater scale than ever before that process of destroying his enemies one by one by which he has so long thrived and prospered, and that then the scene will be clear for the final act, without which all his conquests would be in vain--namely, the subjugation of the Western Hemisphere to his will and to his system.

7. It is not for me to speak of the action of the United States, but this I will say. If Hitler imagines that his attack on Soviet Russia will cause the slightest division of aims or 
slackening of effort in the great democracies who are resolved upon his doom, he is woefully mistaken.

Of the above six sentences about will, all indicate Churchill's belief in his propositions. In sentences (1) to (3), Churchill gives his audience information about what Great Britain will do in the future. In sentences (4) to (7), will/would expresses Churchill's prediction of the failure of Hitler, which subjectively shows Churchill's confidence in the failure of Nazism.

When will/shall is following a subject in the first person, it functions as the modulation of inclination, showing the willingness, promise and determination. For example,

We shall fight him by land, we shall fight him by sea, we shall fight him in the air, until, with God's help, we have rid the earth of his shadow and liberated its people from his yoke.

We shall appeal to all our friends and Allies in every part of the world to take the same course and pursue it as we shall, faithfully and steadfastly to the end. ...

We shall bomb Germany by day as well as by night in ever-increasing measure, casting upon them month by month a heavier discharge of bombs and making the German people taste and gulp each month a sharper dose of the miseries they have showered upon mankind.

On the contrary, we shall be fortified and encouraged in our efforts to rescue mankind from his tyranny. We shall be strengthened and not weakened in our determination and in our resources.

In this example, Churchill promises to the British people that they will unite all attempts to fight against Hitler, since people are most likely to focus on what politicians would act to make sure a better situation. The high rate of appearance of shall also shows his determination of winning the war.

\section{Must \& have to}

Must \& have to are the strongest modal auxiliaries, with the former subjective and the latter objective. These modal auxiliaries emphasize the speaker's authority over the audience. For example,

I have to declare the decision of His Majesty's Government,--and I feel sure it is a decision in which the great Dominions will in due course concur--for we must speak of now at once, without a day's delay. I have to make the declaration, but can you doubt what our policy will be?

He wishes to destroy the Russian power because he hopes that if he succeeds in this he will be able to bring back the main strength of his army and air force from the East and hurl it upon this island, which he knows he must conquer or suffer the penalty of his crimes.

In this example, Churchill expresses the irresistible command and order to the audience. He calls on the people to fight against Hitler. "Must" indicates the speaker's subjective view, while "have to" means the objective necessity. The use of both subjective and objective auxiliaries helps to enforce the politician's will upon the audience and thus achieve his goal at last. 


\section{Polarity Analysis}

Polarity is mainly expressed through the Finite. But it may also be expressed through other elements such as Mood Adjuncts, subject, complement, etc, especially when it is negative polarity. The negative polarity appears frequently in Speech. For example,

1. I had not the slightest doubt where our duty and our policy lay, nor indeed what to say.

2. There was not time to consult the War Cabinet, nor was it necessary.

3. I asked whether for him, the arch anti-Communist, this was not bowing down in the House of Rimmon. Mr. Churchill replied, "Not at all. I have only one purpose, the destruction of Hitler, and my life is much simplified thereby.

4. The Nazi regime is indistinguishable from the worst features of Communism

5. No one has been a more consistent opponent of Communism than I have for the last twenty-five years.

6. We will never parley, we will never negotiate with Hitler or any of his gang.

7. This is no class war.

8. It is not for me to speak of the action of the United States.

9. This is no time to moralize upon the follies of countries and governments which have allowed themselves to be struck down one by one when by united action they could so easily have saved themselves and saved the world from this catastrophe.

10. His invasion of Russia is no more than a prelude to an attempted invasion of the British Isles.

11. From this nothing will turn us-nothing.

12. I will unsay no words that I've spoken about it.

Of the above twelve sentences, all polarity is negative. The negative polarity in the first half of sentences (1) and (2), sentences (3), (7), (8), (9) and (10) is expressed through the Finite. In the second half of sentences (1), (2) and sentences (6), it is the Mood Adjuncts that expresses the negative polarity. While in sentences (5) and (11), the subject expresses the negative polarity. In sentence (4), the predicative carries the negative polarity. While in sentence (12), it is the both the Finite and complement that expresse negative polarity.

By employing such a large number of sentences with negative polarity, Churchill emphasizes with great force that there is no space of negotiation, no possibility of drawing back, and no other ways for them to choose. It shows his firm determination to destroy Hitler and the confidence of his own decision.

\section{SUMMARY}

A prominent feature of political discourse is persuasion, and the persuasive intension of the speaker or writer can be conveyed through the language he employs. Choice is meaning (Huang, 2001: 44). As far as mood is concerned, declarative clauses make up a great majority (95.9\%) of all clauses. Declarative clauses mainly state the reality. The high dominance of declarative clauses makes the speech more informative and objective. Therefore, the audience will accept the discourse easily. The modal auxiliaries will, shall, would and must (have to) appear most frequently in this speech. Will and shall indicate high possibility when they function as modalization. They help add the power and emotion to the speech. Would is used when we are not quite sure about things. By using would instead of will, the speaker only expresses his own point of view and let the audience decide whether it is right or not. Must and have to are a pair of strongest modal auxiliaries, with must denoting subjectively while have to objectively. The use of both subjective and objective auxiliaries helps to enforce the politician's will upon the audience. The negative polarity also appears frequently in this speech. It can be 
expressed not only through the Finite, but also through Mood Adjuncts, subject, complement, etc. The use of negative polarity shows the politician's firm determination to achieve his goal at last.

\section{References}

Halliday, M.A.K. 1994/2000. An Introduction to Functional Grammar. Beijing: Foreign Language Teaching and Research Press.

何莎, 2006, 《从批评性语篇分析角度分析乔治.布什演讲中的说服力的体现》（硕士学位论文）。广州：广东 外语外贸大学。

黄国文, 2001, 《语篇分析的理论与实践一广告语篇分析》。上海：上海外语教育出版社。

农德昌, 2006, 《对马丁.路德.金的<我有一个梦想的元功能>分析》（硕士学位论文）。南宁：广西大学。 